\title{
The effect of ellagic acid on photodynamic therapy in leukemia cells
}

\author{
Dan Sun ${ }^{1}$, Yao Lu ${ }^{1}$, Su-Juan Zhang ${ }^{1}$, Kai-Ge Wang ${ }^{1}$ and Yuan $\mathrm{Li}^{2}$ \\ ${ }^{1}$ National Center for International Research of Photoelectric Technology and Nano-functional Materials, State Key Labora- \\ tory of Cultivation Base for Photoelectric Technology and Functional Materials, Key Laboratory of Optoelectronic Technol- \\ ogy of Shaanxi Province, Institute of Photonics and Photo-Technology, Northwest University, Xian, 710069, PR China \\ ${ }^{2}$ Xian Zunde Middle School, Xian, 710100, PR China
}

\begin{abstract}
Ellagic acid (EA) is a naturally phenolic acid presented in different foods. It has a variety of biological activities including antioxidant, anti-inflammatory, anti-microbiological and anti-cancer properties. On account of its antioxidant activity, EA might protect cancer cells from free radical damage in photodynamic therapy (PDT) during which reactive oxygen species (ROS) production was stimulated leading to irreversible tumor cell injury. In this study, the influence of EA on K562 cells in 5-aminolevulinic acid (ALA)-based PDT is demonstrated. Cell apoptosis was assayed by flow cytometry. Oxidative damage induced by PDT was investigated by measurement of malondialdehyde (MDA). Comet assay was used to evaluate the potential genotoxic effect induced by PDT on the cells. The results showed that EA supplementation alone did not affect the lipid peroxidation, DNA damage and apoptosis in K562 cells. It increases the lipid peroxidation, DNA damage, apoptosis and decreases the survival rate in K562 cells induced by ALA-PDT. The singlet oxygen quencher sodium azide suppresses apoptosis, lipid peroxidation and DNA damage induced by EA in PDT. In conclusion, EA consumption during PDT did not decrease the effectiveness of cancer therapy on malignant cells. The effect of antioxidants on PDT maybe was determined by its sensitization ability to singlet oxygen.
\end{abstract}

Key words: Ellagic acid - Reactive oxygen species — Photodynamic therapy — Sodium azide Leukemia K562

\section{Introduction}

Photodynamic therapy (PDT) is an approved treatment for several types of cancer as well as for age-related macular degeneration (Martijn et al. 2006). Clinical trials continue to expand the role of PDT in cancer and in the treatment of localized microbial infections, as reviewed in (Brown et al. 2000; Agostinis et al. 2011). PDT includes loading of the target cells with a photosensitizer and subsequent illumination with visible light (Ion 2010). When the oxygen is present, the combination of light and photosensitizer causes generation of reactive oxygen species (ROS), in particular singlet oxygen

Correspondence to: Dan Sun, National Center for International Research of Photoelectric Technology and Nano-functional Materials, State Key Laboratory of Cultivation Base for Photoelectric Technology and Functional Materials, Key Laboratory of Optoelectronic Technology of Shaanxi Province, Institute of Photonics and Photo-Technology Northwest University, Xi'an, 710069, PR China E-mail: sund@nwu.edu.cn $\left({ }^{1} \mathrm{O}^{2}\right)$, superoxide anion and hydroxyl radical (Glasauer and Chandel 2014), resulting in target cell death either through necrosis or apoptosis (Acedo et al. 2014).

The initial photochemical processes leading to cell death may follow two principal pathways: The photosensitizer molecule absorbs a light photon and becomes an excited triplet state (Castano et al. 2006; Garland et al. 2009). The excited photosensitizer molecule can then transfer energy to molecular oxygen to produce singlet oxygen (type II reaction) or suffer electron transfer (type I reaction) to form superoxide radical anion and/or hydroxyl radicals (Mroz et al. 2010; Ogilby et al. 2010). Both pathways can occur simultaneously and the ratio between them depends on the photosensitizer and the nature of the substrate. However, direct and indirect evidence supports a prevalent role for ${ }^{1} \mathrm{O}^{2}$ in the molecular processes initiated by PDT (Niedre et al. 2002; Agostinis et al. 2011). 5-Aminolevulinic acid (ALA) is the precursor of photosensitizer protoporphyrin IX (PPIX) in the biosynthetic pathway of heme. Following the exogenous administration of ALA, tumors selectively accumulate PPIX, 
which under suitable irradiation generates either cytotoxic species leading to cellular damage. Therefore, ALA is widely used as a topical drug in PDT (Wu et al. 2003; Zhang and Zhang 2004).

Consumption of fruits and vegetables is known to lower the risk of several diseases. Such health benefits are mainly attributed to the content of antioxidant compounds most notably polyphenols including gallic and ellagic acids, as reviewed in (Crozier et al. 2009). Ellagic acid (EA) is a naturally polyphenolic compound found in different fruits and nuts like pomegranate, red raspberry, strawberry, blue berry and walnut. It has a variety of biological activities including antioxidant (Rehman et al. 2012), antiinflammatory (Rogerio et al. 2008), anti-microbiological (Zambuchini et al. 2008) and anti-cancer (Oidovsambuu et al. 2013; Zhao et al. 2013) properties. The anti-cancer properties of EA include induction of cell cycle arrest and apoptosis (Larrosa et al. 2006). The molecular mechanisms responsible for these effects remain largely unknown, but its potent scavenging action on ROS might be involved (Rehman et al. 2012).

The mechanism of PDT exerted on tumor cell killing is the production of ROS. These oxidative actions may be modified by the phytochemicals present in food. Although studies involving use of antioxidants during cancer therapy are promising, research on this topic is still scarce and controversial (González et al. 2005, 2006; Ozben 2007). Studies indicate that supplementation with dietary antioxidants may improve the efficacy of radiation therapy by increasing tumor response and decreasing some of its toxicity on normal cells (Prasad et al. 2001). The other suggests that dietary antioxidants should not be used during radiation therapy, because they would protect cancer cells against radiation damage (Salganik 2001). Each of these is based on different conceptual frameworks that are derived from results obtained from specific experimental designs, and thus, each may be correct within its parameters.

Ellagic acid has antioxidant properties and it was popular in diet and medicine (Türk et al. 2010). It should be noticed that any antioxidant found to reduce toxicity of tumor therapy on healthy tissue has the potential to decrease effectiveness of cancer therapy on malignant cells. To assess whether EA interferes with ALA-PDT treatment, the present study investigated the antioxidant activity of EA and demonstrated the influence of EA on PDT.

\section{Material and Methods}

\section{Chemical reagents}

5-aminolevulinic acids, L-glutamine, trypan blue and EA were purchased from Sigma Co., Ltd. (USA), RPMI-1640 medium was from Gibco Co., Ltd. (USA). Dimethyl sulfoxides (DMSO), penicillin and streptomycin were obtained from Solarbio (China). Newborn calf serum (NCS) was from Sijiqing (China). Annexin V-FITC-PI Apoptosis Detection Kit was obtained from centre-Bio Co., Ltd. (China). Other chemicals used in the present study were of analytical grade.

\section{Equipments}

Apoptosis was analyzed on a four-color fluorescence capability FACScalibur flow cytometer (BD Biosciences, USA). The fluorescence spectra were measured with the 970CRT fluorophotometer (Shanghai SANCO Instrument Co., Ltd, China). The fluorescence images of comet assay were examined with a fluorescence microscope (Olympus, Japan). The radiation source was a xenon lamp (USHIO, Japan).

\section{Cell culture}

K562 cells were cultured in RPMI 1640 medium supplemented with $10 \%(\mathrm{v} / \mathrm{v})$ newborn calf serum, $1 \%(\mathrm{v} / \mathrm{v})$ L-glutamine and 100 units $/ \mathrm{ml}$ antibiotics (penicillin and streptomycin) at $37^{\circ} \mathrm{C}$ in $5 \% \mathrm{CO}^{2}$ humidified incubator.

\section{EA treatment}

EA was dissolved in $100 \%$ DMSO and stored at $-20^{\circ} \mathrm{C}$. For the cell growth assay, cells were seeded into six-well plates at a density of $1 \times 10^{5}$ cells $/ \mathrm{ml}$ and were treated with EA or with DMSO only (as control) in triplicates. The final concentration of DMSO was kept at less than $0.05 \%$. For the dose-dependent experiment, cells were treated with EA for $24 \mathrm{~h}$, respectively. For the time-dependent experiment, cells were treated with EA and detected at 12, 24, 36 and $48 \mathrm{~h}$.

\section{Photodynamic treatment}

K562 cells in the exponential phase of growth were harvested and suspended in RPMI 1640 medium at a density of $1 \times 10^{5}$ cells $/ \mathrm{ml}$. Cells were incubated for $4 \mathrm{~h}$ with $1 \mathrm{mM}$ ALA at $37^{\circ} \mathrm{C}$. Then, cells were seeded in six-well plates and illuminated with a light intensity of $350 \mathrm{~mW} / \mathrm{cm}^{2}$ and a light doses of $105 \mathrm{~J} / \mathrm{cm}^{2}$ at $37^{\circ} \mathrm{C}$. $\mathrm{K} 562$ cells were incubated with EA for $20 \mathrm{~min}$ at $37^{\circ} \mathrm{C}$ before ALA-PDT irradiation. The radiation source is a xenon lamp emitting wavelengths over the range $400-800 \mathrm{~nm}$, which encompassed the activation wavelengths for PPIX (420-800 nm).

\section{Cell viability assay}

K562 cells were seeded into 6-well plates at a density of $1 \times 10^{5}$ cells $/ \mathrm{ml}$ incubated at $37^{\circ} \mathrm{C}, 5 \% \mathrm{CO}^{2}$. After experiments, cells 
were stained by $0.2 \%$ trypan blue solution and monitored on a hemacytometer by a light microscopy. The percent of cell survival was calculated as follows:

$\%$ Survival $=($ survival $/$ control $) \times 100 \%$

\section{Determination of MDA}

The analysis of malondialdehyde (MDA) as a marker of lipid peroxidation end products was carried out according to the previous report of Jentzsch et al. (1996). To assay the lipid peroxidation, $2 \mathrm{ml}$ of cells suspensions $\left(3 \times 10^{5}\right.$ cells/ $\mathrm{ml}$ ) were centrifuged at $1000 \mathrm{rpm}$ for $3 \mathrm{~min}$, resuspended in $2 \mathrm{ml}$ Hank's, and mixed with $240 \mu \mathrm{l} 10 \%$ SDS (sodium dodecyl sulphate) at room temperature. After $20 \mathrm{~min}$, the reaction mixture was deproteinized with $1.2 \mathrm{ml} 10 \%$ trichloroacetic acid for $10 \mathrm{~min}$. Then, $1 \mathrm{ml}$ homogenate was centrifuged at $4000 \mathrm{rpm}$ for $10 \mathrm{~min}$, the lysate was resuspended in $4 \mathrm{ml}$ distilled water in a tube, and $1 \mathrm{ml}$ of $0.45 \%$ thiobarbituric acid was added. This tube was boiled for $1.2 \mathrm{~h}$ and cooled for $2-3 \mathrm{~min}$ at room temperature. Then $2.5 \mathrm{ml} \mathrm{n}$-butanol was added and centrifuged at $3000 \mathrm{rpm}$ for $15 \mathrm{~min}$. The supernatant was obtained and the fluorescence intensity at $546 \mathrm{~nm}$ was determined using a fluorophotometer excited at $530 \mathrm{~nm}$. The standards of MDA were prepared by acid hydrolysis of 1,1,3,3-tetramethoxypropane. A calibration curve was used to calculate MDA concentration, and results were expressed in nanograms of MDA per $10^{6}$ cells.

\section{Flow cytometry}

Cell apoptosis was assayed by using Annexin V-FITC-PI apoptosis detection kit. Cells were washed twice with cold $\operatorname{PBS}\left(0^{\circ} \mathrm{C}\right)$ and resuspended in binding buffer at $1 \times 10^{6}$ cells/ $\mathrm{ml}$. First, $400 \mu \mathrm{l}$ cells solution was incubated with $10 \mu \mathrm{l}$ of $20 \mu \mathrm{g} / \mathrm{ml}$ Annexin V-FITC for $15 \mathrm{~min}$ at $4-8^{\circ} \mathrm{C}$ in the dark, then incubated with $10 \mu \mathrm{l}$ of $50 \mu \mathrm{g} / \mathrm{ml}$ PI for another $5 \mathrm{~min}$ at $4-8^{\circ} \mathrm{C}$ in the dark, and finally analyzed by flow cytometry at room temperature.

\section{Comet assay}

DNA damage was quantified by the comet assay as described previously (Singh et al. 1988). Cell solution at $3 \times 10^{5}$ cells $/ \mathrm{ml}$ in cool PBS $\left(0^{\circ} \mathrm{C}\right)$ mixed with same volume of $1 \%$ low melting point agarose in $\mathrm{PBS}$ was pipetted onto glass slides on ice precoated with $2 \%$ normal melting point agarose. After $10 \mathrm{~min}$, the slides were incubated in lysis buffer $(200 \mathrm{mM}$ $\mathrm{NaOH}, 2.5 \mathrm{M} \mathrm{NaCl}, 100 \mathrm{mM}$ EDTA-Na ${ }^{2} .2 \mathrm{H}^{2} \mathrm{O}$ and $1 \%$ (w/v) N-lauroyl sarcosine (sodium salt), $\mathrm{pH}$ 12.5-13.0) at $0^{\circ} \mathrm{C}$ for $1 \mathrm{~h}$. Slides were then washed and incubated in alkaline unwinding buffer $(300 \mathrm{mM} \mathrm{NaOH}$ and $1 \mathrm{mM}$ EDTA- $\mathrm{Na}^{2} .2 \mathrm{H}^{2} \mathrm{O}$, pH $12.5-13.0$ ) for $20 \mathrm{~min}$. Following electrophoresis for $20 \mathrm{~min}$ at $6.28 \mathrm{~V}$ in unwinding buffer, nuclei were stained with $0.02 \%(\mathrm{v} / \mathrm{v})$ ethidium bromide for $20 \mathrm{~min}$ at room temperature. Digital images of 30 cells were randomly captured for analysis by Casp-2.2 analysis software. "\% DNA in tail" was calculated as the extent of DNA damage.

\section{Statistical analysis}

Data were processed using EXCEL analysis software (Microsoft Co., Washington, USA) and expressed as means \pm SD. Differences between the groups were assessed by the two-tailed Student's t-test for unpaired samples. Results were considered significantly different when $p<0.05$ was obtained.

\section{Results}

\section{Influence of EA on cell survival}

To analyze the effect of EA on K562 cell growth/proliferation, we treated $\mathrm{K} 562$ cells cultures with different concentrations of EA $(0-100 \mu \mathrm{M})$ for $48 \mathrm{~h}$. As showed in Fig. 1, EA inhibited cell proliferation in a time-dependent manner. After $48 \mathrm{~h}$ incubation, the viable cells in the culture treated with EA were reduced comparing with those in control $(p<0.05)$. While the concentration of EA was $10 \mu \mathrm{M}$, the lowest concentration used in this study, also have antiproliferative activity $(p<$ 0.05). Cell apoptosis was examined by flow cytometry using

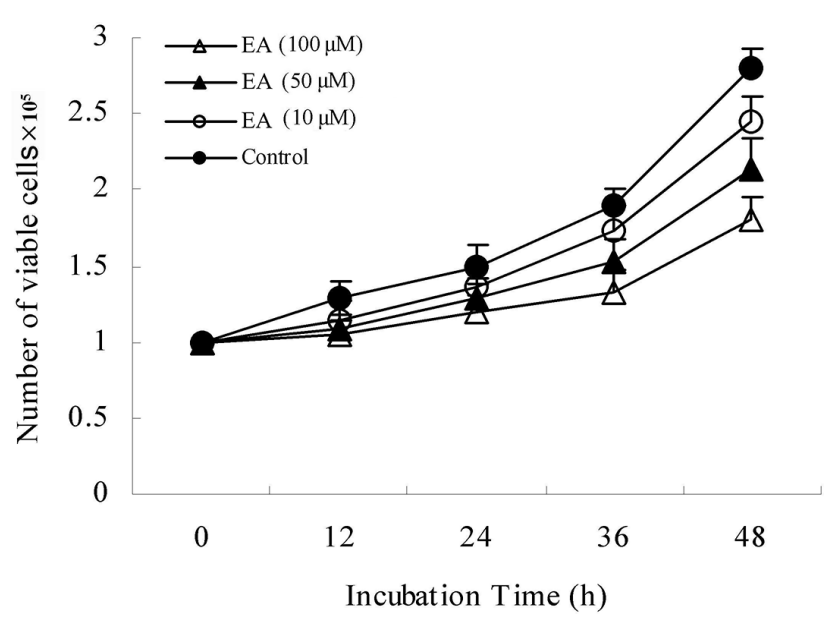

Figure 1. Ellagic acid (EA) inhibits K562 cells growth. Equal amounts of inoculants $\left(1.0 \times 10^{5}\right.$ viable cells $)$ were seeded in the cultures containing different concentration of EA $(0-100 \mu \mathrm{M})$. Results represent means \pm SD of three independent experiments. 


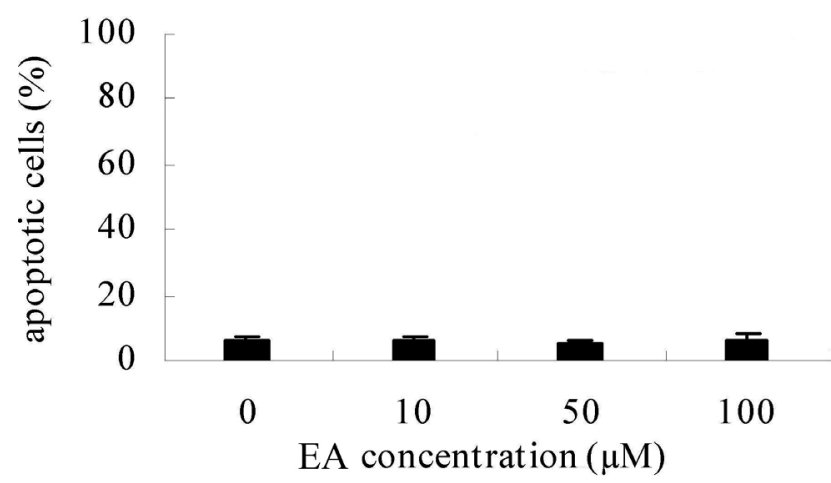

Figure 2. Effects of EA on apoptotic. The data were assessed $24 \mathrm{~h}$ incubation. Results represent means \pm SD of three independent experiments.

Annexin V-FITC-PI Apoptosis Detection Kit. The result indicates that EA $(0-100 \mu \mathrm{M})$ could not induce apoptosis in K562 cells $24 \mathrm{~h}$ after incubation (Fig. 2)

\section{Influence of EA on cell survival in ALA-PDT treatment}

To investigate the effect of EA on PDT we measured cell survival and cell apoptosis after EA and PDT treatment. As showed in Fig. 3, Incubation cell with light alone or ALA alone in the dark did not decrease cell viability. After cell with ALA and light, cell survival was significantly decreased. Approximately $35 \%$ cells survived in the ALA-PDT. In comparison

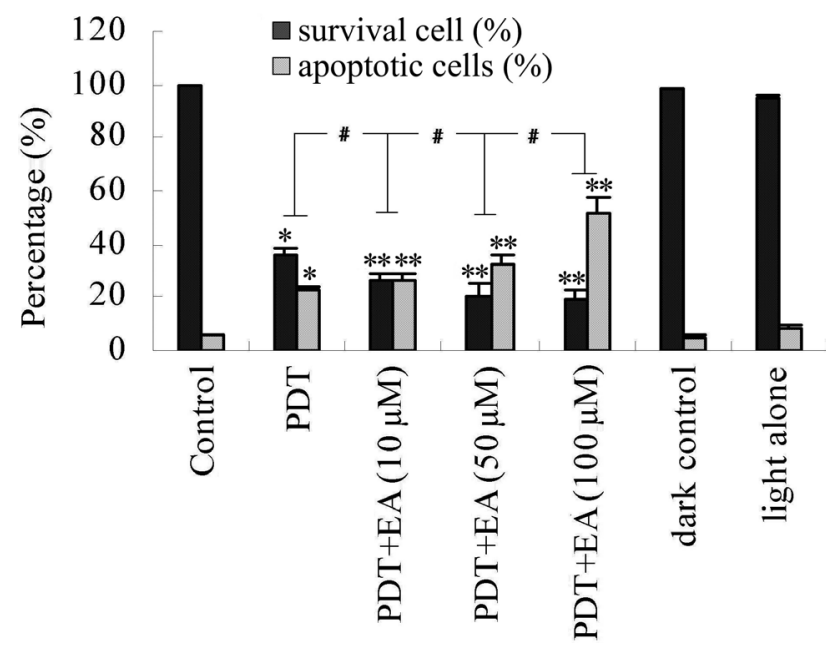

Figure 3. Effects of EA on cell survival and apoptotic $24 \mathrm{~h}$ after ALA-PDT irradiation. K562 cells were incubated $20 \mathrm{~min}$ prior ALA-PDT irradiation with different concentrations of EA $(0-100 \mu \mathrm{M})$. Results represent means \pm SD of three independent experiments. $\# p<0.05 ;{ }^{*} p<0.05 v s$. control; ${ }^{* *} p<0.05 v s$. ALA-PDT. with untreated cells (control) the increase in apoptosis (approximately 20\%) was observed after ALA-PDT treatment.

When cells were exposed to EA and PDT, a dose-dependent decrease in cell survival was observed compared to cells exposed to PDT alone (Fig. 3, $p<0.05$ ). Cell apoptosis were examined by flow cytometry. In comparison with untreated cells (control), the increase in apoptosis $(22.87 \%)$ was observed after ALA-PDT treatment. EA enhanced the apoptosis induced by ALA-PDT in a dose-dependent manner (Fig. 3). When EA supplemented together with sodium azide $\left(\mathrm{NaN}^{3}, 100\right.$ $\mu \mathrm{M})$ under the same condition, EA could not enhanced the apoptosis in K562 cells induced by ALA-PDT (Fig. 4, $p>0.05$ ).

\section{Influence of EA on lipid peroxidation and DNA damage in ALA-PDT treatment}

In parallel with measurement of the influence of EA and PDT on cell survival, we examined the lipid peroxidation and DNA damage after treatments. Result was assessed $24 \mathrm{~h}$ after ALA-PDT irradiation. MDA produced was measured to evaluate the lipid peroxidation. MDA amount was determined by measuring the change of fluorescence intensity by the fluorophotometry. DNA damage was quantified with the comet assay. "\% DNA in tail" was calculated as the extent of DNA damage. K562 cells were incubated with EA for $20 \mathrm{~min}$ at $37^{\circ} \mathrm{C}$ before ALA-PDT irradiation. EA supplementation alone did not affect the MDA concentration

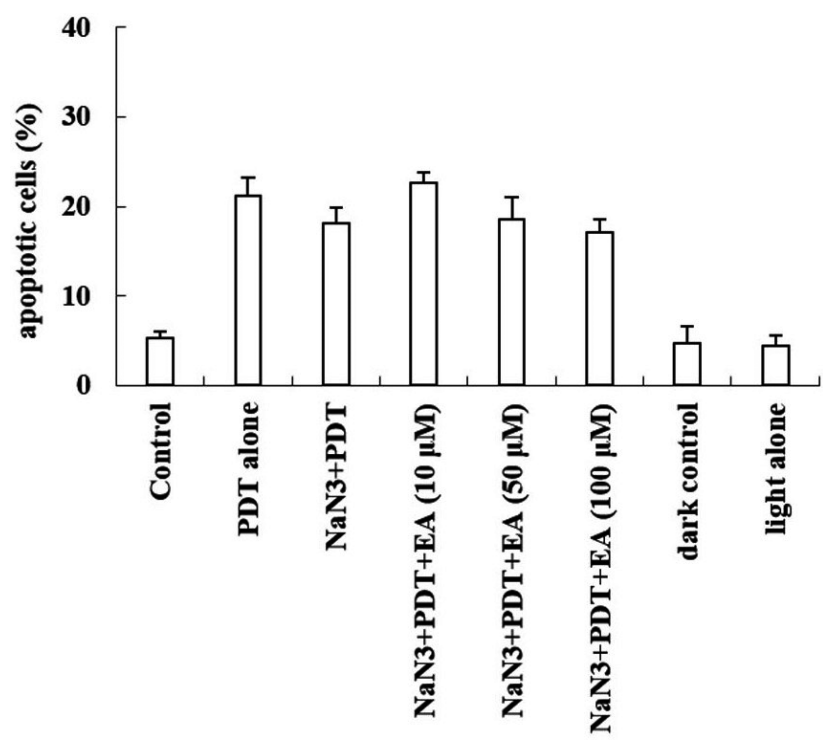

Figure 4. Effects of $\mathrm{NaN}^{3}$ combined with EA on apoptotic in ALA-PDT treatment. K562 cells were incubated 20 min prior ALAPDT irradiation with different concentrations of EA $(0-100 \mu \mathrm{M})$ and $\mathrm{NaN}^{3}$. Results represent means $\pm \mathrm{SD}$ of three independent experiments. 
and percentage DNA in tail compared to control cells as showed in Figs. 5A and 6A ( $p>0.05)$. Significant increase in the amounts of MDA and level of DNA damage was found in K562 cells after ALA-PDT treatment compared with control cells or cells treated with ALA dark (dark control) or light alone (Figs. 5B and 6B, $p<0.05)$. EA $(0-100 \mu \mathrm{M})$ enhanced the lipid peroxidation and DNA damage in K562 cells induced by ALA-PDT $(p<0.05)$. With regard to the effect of EA supplemented together with sodium azide on PDT-induced DNA damage and lipid peroxidation in K562 cells, DNA strand breakage and MDA amount in only PDT together with sodium azide group and supplemented EA group was not significantly different (Figs. 7 and $8, p>0.05$ ).

\section{Discussion}

Dietary antioxidants, such as vitamin E, ascorbic acid, and polyphenols, have been shown to have protective effects
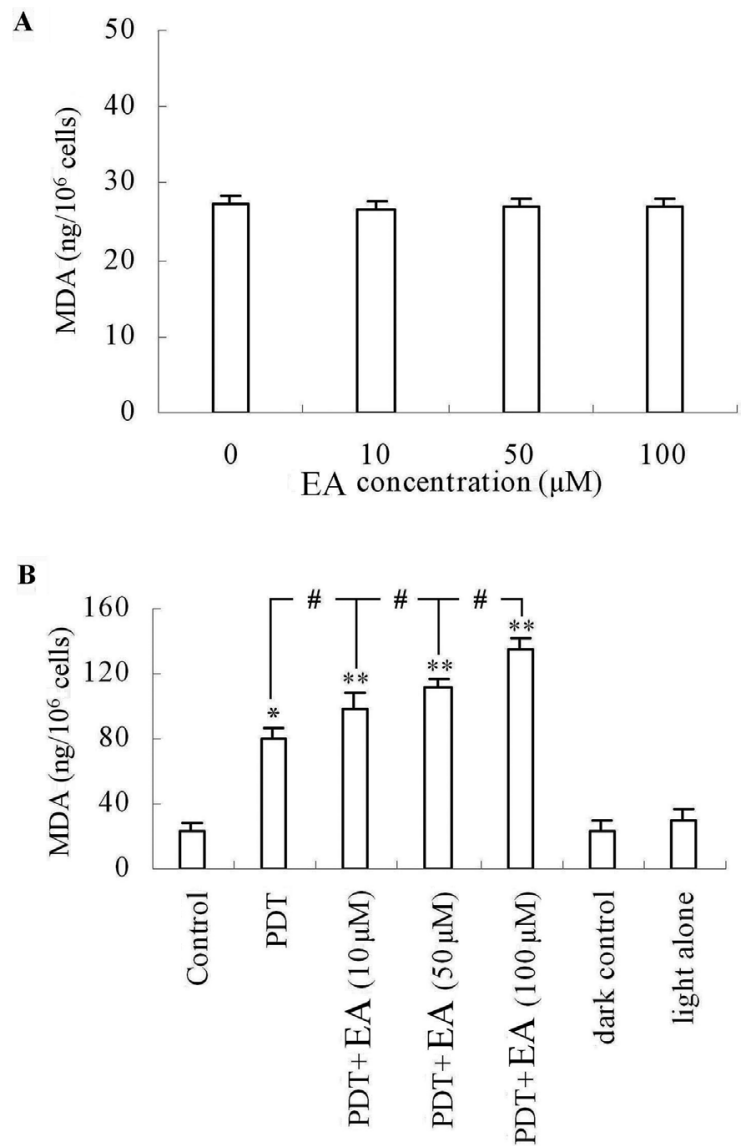

Figure 5. Influence of EA on lipid peroxidation in K562 cells with (A) and without (B) PDT treatment (24 h incubation). Results represent means \pm SD of three independent experiments. $\# p<0.05$; ${ }^{*} p<0.05 v s$. control; ${ }^{* *} p<0.05$ vs. ALA-PDT.
A

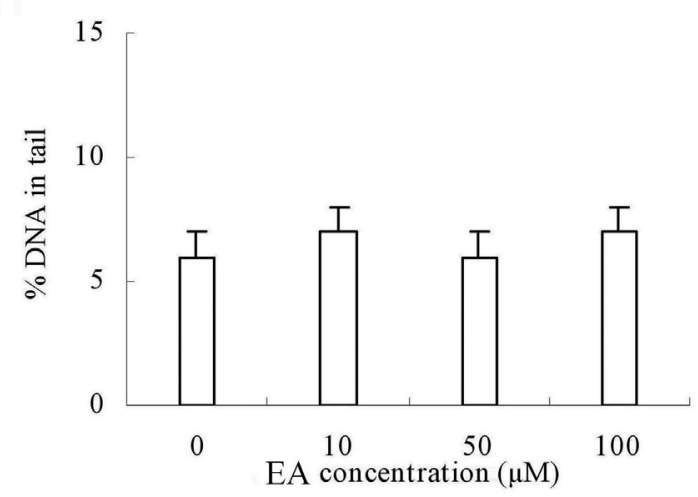

B

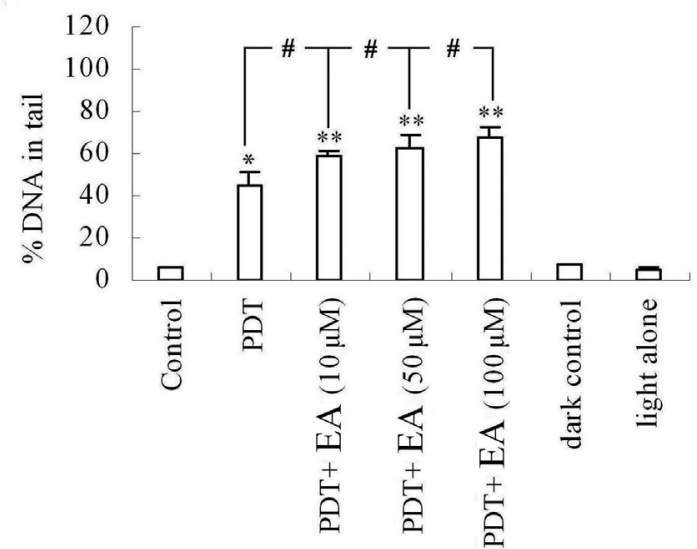

Figure 6. Influence of EA on DNA damage in K562 cells with (A) and without (B) PDT treatment ( $24 \mathrm{~h}$ incubation). Results represent means \pm SD of three independent experiments. $\# p<0.05 ;^{*} p<0.05$ vs. control; ${ }^{* *} p<0.05 v$ s. ALA-PDT.

against a number of diseases in humans, including cancer and heart disease, as well as to be able to counteract the deleterious effects of many carcinogens. The beneficial effects of these compounds are typically credited to their antioxidant activities, although inhibition of cellular mediators of cell death, including protein kinases and eicosanoids has also been postulated (Gopalakrishna and Gandimeda 2002).

It has been suggested that EA biological effects may be partially due to its high free-radical scavenging activity (Rehman et al. 2012). EA is a phenolic compound that has been shown previously to have potent anticarcinogenic/ anti-mutagenic properties, in addition to its strong antioxidant activity (Pari and Sivasankari 2008). EA has hydrogen atoms available for abstraction and can remain stable through delocalization of electrons across the conjugated ring and side chains. Also, these hydrogen atoms may form hydrogen bonds reducing free radicals affinity to the DNA. Several studies indicated that EA had a scavenging action against both oxygen and hydroxyl radicals, and inhibited 


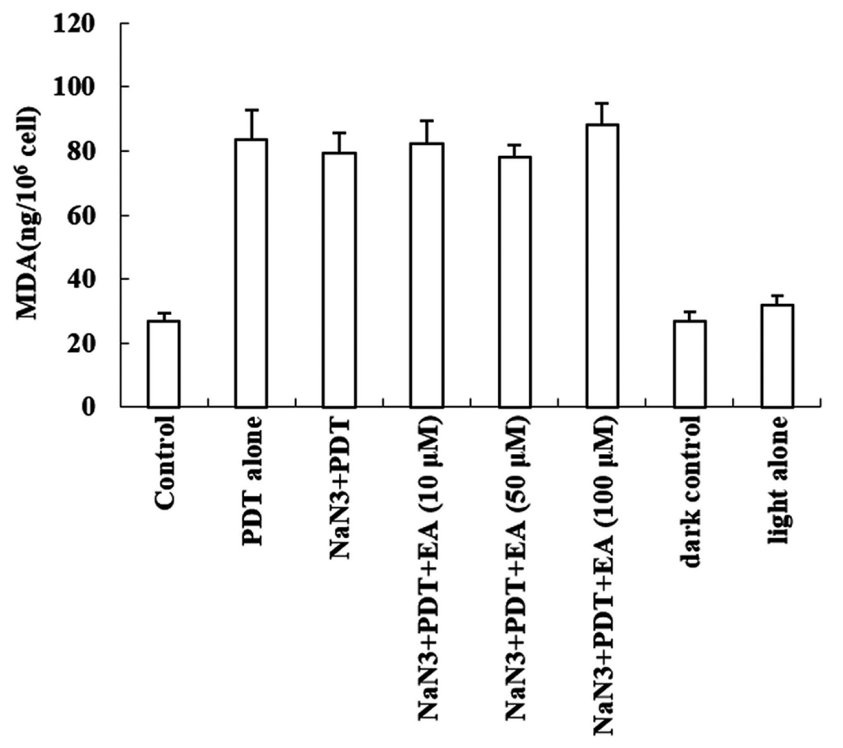

Figure 7. Effects of $\mathrm{NaN}^{3}$ combined with EA on lipid peroxidation in PDT treatment. K562 cells were incubated $20 \mathrm{~min}$ prior ALA-PDT irradiation with different concentrations of EA $(0-100 \mu \mathrm{M})$ and $\mathrm{NaN}^{3}$. Results represent means \pm SD of three independent experiments.

lipid peroxidation and 8-OhdG formations in vitro and in vivo (Laranjinh et al. 1996; Vattem and Shetty 2003). Such findings implied that EA may decrease the effectiveness of cancer therapy which produces ROS to kill malignant cells. The present study focuses on the effect of EA on ROS-mediated ALA-PDT in K562 cells. The cell line K562 which is derived from the patient with chronic myelogenous leukaemia (CML) is commonly employed as the "in vitro" model of the blast phase of this disease.

It is apparent that high numbers of cancer patients are using antioxidants with or without the knowledge of their oncologist. The use of antioxidants during cancer therapy is currently a debated topic because of some contradictory findings (Akbas et al. 2006; Al-Sherbini et al. 2009; Sun et al. 2009). Some data indicate that antioxidants can protect healthy cells and tissues from the damage of free radical without affecting treatment efficacy (Akbas et al. 2006). On the other hand, other researches suggested that antioxidant decrease the effectiveness of cancer therapy on malignant cells (Richardson et al. 2000; Seifried et al. 2003). Combining these results, further research on antioxidants and chemotherapy are now warranted. This research mainly discusses the influence of EA on PDT.

Only a few studies have been published to date concerning antioxidants in photodynamic treatment. The role of antioxidants in PDT is only marginally examined. Frank et al. discovers that increasing intracellular concentrations of vitamin $\mathrm{C}$ contribute to the resistance of cultured cancer cells

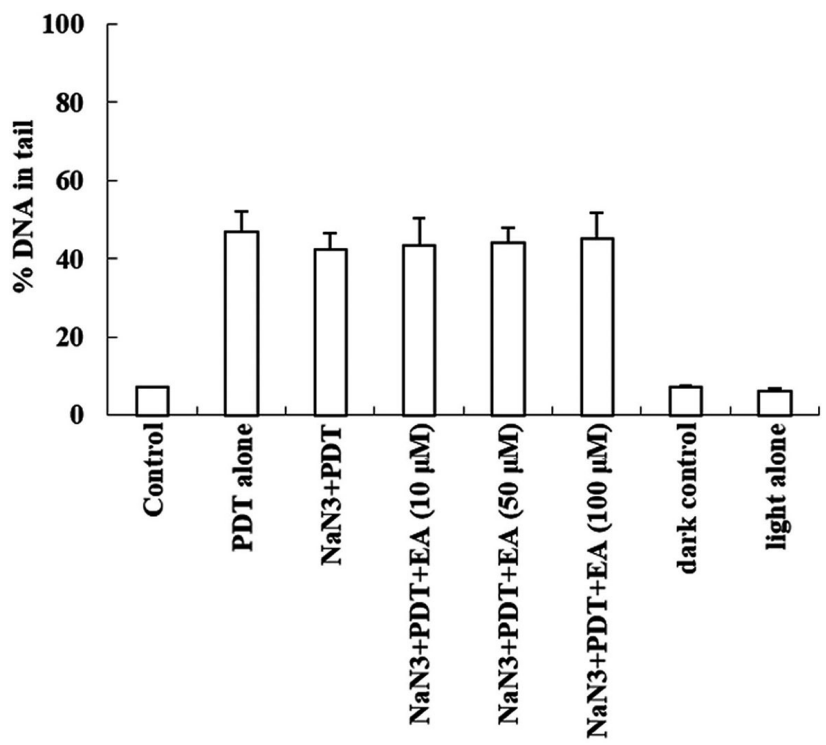

Figure 8. Effects of $\mathrm{NaN}^{3}$ combined with EA on DNA damage in PDT treatment. K562 cells were incubated 20 min prior ALAPDT irradiation with different concentrations of EA $(0-100 \mu \mathrm{M})$ and $\mathrm{NaN}^{3}$. Results represent means $\pm \mathrm{SD}$ of three independent experiments.

to prooxidant treatment modalities as ALA-PDT (Frank et al. 2006). Al-Sherbini et al. (2009) found that high concentrations of vitamin E enhance the PDT action against HeLa cervical cancer cell line. Rubio and colleagues (Rubio et al. 2014) demonstrates that in PDT-treated cells a p38MAPK-regulated pathway coordinates the p62/NBR1mediated clearance of cytosolic aggregates and mitigates PDT-induced proteotoxicity. Peter Ferenc and colleagues (Ferenc et al. 2010) demonstrated that pre-treatment with tyrosine kinase inhibitor genistein may significantly improve the effectiveness of PDT with hypericin in MCF-7 and MDA-MB-231 breast cancer cells. Our previous study (Zhang et al. 2012) found the soyabean isoflavones genistein and daidzein did not decrease the effectiveness of cancer therapy on malignant cells.

Ellagic acid is one of the most interesting substances with proapoptotic and antioxidant action that determines apoptosis, down regulation of IGF-II, activates p21 (waf1/ Cip1) a cyclin-dependent kinase inhibitor able to arrest the cell cycle at the G1, and prevents destruction of p-53 gene by cancer cells. Some studies have reported that EA induces cell cycle arrest and/or apoptosis in several cancer cell lines (Losso et al. 2004; Mertens et al. 2004; Seeram et al. 2005). Larrosa et al. (2006) found a time- and dose-dependent inhibition of proliferation in cultures of the human colon cancer cell line Caco-2 after treatment with 1,10 or $30 \mu \mathrm{M}$ EA. Li et al. (2005) have reported that EA's antiproliferative effect was associated with cell-cycle: cells increased in the $G^{0} / G^{1}$-phase and decreased in the $G^{2} / M$-phase in human 
bladder cancer T24 cells after treatment with $5,10,25$ or 50 $\mu \mathrm{M}$ EA. As showed in Fig. 1, after $48 \mathrm{~h}$ of incubation, the viable cells in the cultures treated with EA were reduced when compared with those in the untreated cell cultures, but it was not reduced when compared with the amounts of inoculants $\left(1.0 \times 10^{5}\right.$ viable cells). The present study sustains that EA is a potent inhibitor of growth in the K562 cells in vitro and the growth inhibition by EA may due to cell cycle arrest. EA induce cell cycle arrest may induce K562 cells more sensitive to the toxicity of PDT.

In our study, we focused on the effect of EA on ROSmediated cancer therapy. 5-Aminolevulinic acid-mediated photosensitization results in the formation of excessive amounts of ROS. ROS have been implicated in the induction of various types of oxidative damage to biomolecules that result several pathological events in living organisms (Ziech et al. 2010). It can induce changes in different biological tissues and cell biomolecules such as lipids, proteins, DNA or RNA (Cooke et al. 2003). Cell apoptosis was assayed by flow cytometry in present study. Oxidative damage induced by PDT was investigated by measurement of malondialdehyde (MDA), a marker of lipid peroxidation. Peroxidation of lipids is particularly destructive because the formation of lipoperoxidation products leads to a facile propagation of free radicals and membrane disintegration. Comet assay used to evaluate the potential genotoxic effect induced by PDT on the cells. It has been widely used in toxicology, radiation biology, and was introduced into the field of PDT. Comet assay is a useful technique for the detection of DNA single- and double-stranded breaks, and alkali-labile sites in individual cells after treatment with genotoxins. The major advantages of the comet assay over other methods of measuring DNA damage is that information is acquired about the distribution of DNA damage and repair in individual cells within the population, providing an intracellular distribution of damage.

The present study found that EA supplementation alone did not affect the cell apoptosis (Fig. 2), but it increased the apoptosis in K562 cells induced by ALA-PDT (Fig. 3). EA supplementation alone did not affect the MDA concentration and the level of DNA damage compared to control cells (Figs. 5A and 6A), but its supplementation increased the amounts of MDA and the level of DNA damage in ALA-PDT treatment compared to PDT treatment alone (Figs. 5B and $6 \mathrm{~B})$. These results imply that the direct effect of EA may not contribute to the enhancement of PDT-induced cytotoxicity in K562 cells and EA exhibits a synergistic effect on PDT. The exact reasons for the EA enhancement of radiation damage on cancer cells are unknown. We propose the following: (1) the treatment of tumor cells with antioxidant before irradiation can initiate changes in expressions of those genes which can cause differentiation, growth inhibition and/or apoptosis (Israel et al. 2000, Fig. 1), and this damage will continue to progress during the entire period of radiation therapy; and (2) antioxidant can inhibit the repair of radiation damage in cancer cells more than that in normal cells (Rutz and Little 1981).

Ellagic acid enhancements of the PDT-induced cytotoxicity in K562 cells are contradictory to the findings that it is an antioxidant that can scavenge hydroxyl radical, superoxide anion, and hydrogen peroxide. It is known that although both superoxide anion and hydroxyl radical are potentially cytotoxic, most of the oxidative damage in PDT is caused by the singlet oxygen (Agostinis et al. 2011). The different ROS have different signaling and damaging capabilities. Since singlet oxygen is highly reactive and cannot interconvert with endogenous ROS species, it is more likely to cause damage than to elicit signal transduction. Moreover, sodium azide suppresses apoptosis (Fig. 4), lipid peroxidation (Fig. 7) and DNA damage (Fig. 8) in K562 cells induced by EA in PDT support this hypothesis. These results imply that singlet oxygen could be involved in the enhance cytotoxicity effects of the EA in PDT. The finding of singlet oxygen involved in the enhance cytotoxicity effects of the EA in PDT implied that the contradicted findings on the use of antioxidants during cancer therapy may be resulted from the different sensitization activity of antioxidants on singlet oxygen. The antioxidants which can scavenge singlet oxygen may decrease the effectiveness of PDT (such as vitamin C (Frank et al. 2006)). The antioxidants which increase the amounts of singlet oxygen may exhibit a synergistic effect on PDT (such as genistein (Zhang et al. 2012), EA (in this research)).

Some research also found that EA showed significant free radical-scavenging activity which may not contribute to their antioxidant activity. Instead, EA may show antioxidant activity by inducing endogenous antioxidants such as GSH (Bhosle et al. 2005; Türk et al. 2010). This perspective may be another explanation why EA didn't have a protective effect on K562 cells. It is known that antioxidant levels are comparatively higher in normal cells than in tumor cells. Cell malignancy or transformation is often accompanied by a decrease in activity of antioxidant enzyme (SOD, catalase, GSH-Px), which increases the cell sensitivity to prooxidant compounds (Brevard et al. 2002). The susceptibility of tumor cells to radiation or drug is associated with decreased level of antioxidants (Zhang et al. 2002; Dal-Pizzol et al. 2003; Clichici et al. 2010). If EA had direct scavenging ability, a protective effect on cancer cells would be expected. In contrast, if EA revealed antioxidant activity by inducing endogenous antioxidants, a selective effect by different mechanisms could be expected in regards to inducing antioxidant enzymes between cancer cells and normal cells. Cells contain a large number of antioxidants to prevent, or repair the damage caused by ROS. Antioxidant enzyme levels are variable in most animal and human cancers, but often higher 
in human tumors compared to normal tissue (Cairns et al. 2011). However, the exact mechanism of EA show antioxidant activity by inducing endogenous antioxidants in cells needed to be explored.

In conclusion, the results proved that EA enhanced the cell death in K562 cells induced by ALA-PDT. EA supplementation alone did not affect the lipid peroxidation, DNA damage and apoptosis in K562 cells. It increases the lipid peroxidation, DNA damage, apoptosis and decreases the survival rate in K562 cells induced by ALA-PDT. The singlet oxygen quencher sodium azide suppresses apoptosis, lipid peroxidation and DNA damage in K562 cells induced by EA in PDT. Consequently, these results implied that EA consumption during PDT did not decrease the effectiveness of cancer therapy on malignant cells and singlet oxygen could be involved in this process.

Acknowledgement. This study was financially supported by "Scientific research fund project of the Education Department of Shaanxi Province (15JK1732)", "Natural Science Foundation of Shaanxi Province (2014JQ1044)" and "The Science Foundation of Northwest University (12NW01)".

\section{References}

Acedo P, Stockert JC, Ca-ete M, Villanueva A (2014): Two combined photosensitizers: a goal for more effective photodynamic therapy of cancer. Cell. Death Dis. 5, e1122

https://doi.org/10.1038/cddis.2014.77

Agostinis P, Berg K, Cengel KA, Foster TH, Girotti AW, Gollnick SO, Hahn SM, Hamblin MR, Juzeniene A, Kessel D, et al. (2011): Photodynamic therapy of cancer: an update. CA Cancer J. Clin. 61, 250-281 https://doi.org/10.3322/caac.20114

Akbas HS, Timur M, Ozben T (2006): Concurrent use of antioxidants in cancer therapy: an update. Expert. Rev. Clin. Immunol. 2, 931-939 https://doi.org/10.1586/1744666X.2.6.931

Al-Sherbini AM, ElNoury AH, ElRouby MN, Ibrahim T (2009): Vitamin E (a-tocopherol) enhances the PDT action of hematoporphyrin derivatives on cervical cancer cells. Med. Laser Appl. 24, 65-73 https://doi.org/10.1016/j.mla.2008.11.004

Bhosle SM, Huilgol NG, Mishra KP (2005): Enhancement of radiation-induced oxidative stress and cytotoxicity in tumor cells by ellagic acid. Clin. Chim. Acta 359, 89-100 https://doi.org/10.1016/j.cccn.2005.03.037

Brevard A, Agar-Blanc A, Alvarez S, Drane P, Rhun YL, Paris F, Luccioni C (2002): Correlation between antioxidant status, tumorigenicity and radiosensitivity in sister rat cell lines. Carcinogenesis 23, 705-711 https://doi.org/10.1093/carcin/23.5.705

Brown SB, Brown EA, Walker I (2000): The present and future role of photodynamic therapy in cancer treatment. Lancet Oncol. 5, 497-508
https://doi.org/10.1016/S1470-2045(04)01529-3

Cairns RA, Harris IS, Mak TW (2011): Regulation of cancer cell metabolism. Nat. Rev. Cancer 11, 85-95 https://doi.org/10.1038/nrc2981

Castano AP, Pawel M, Hamblin MR (2006): Photodynamic therapy and anti-tumor immunity. Nat. Rev. Cancer 6, 535-545 https://doi.org/10.1038/nrc1894

Clichici S, Filip A, Daicoviciu D, Ion RM, Mocan T, Tatomir C, Rogojan L, Olteanu D, Muresan A (2010): The dynamics of reactive oxygen species in photodynamic therapy with tetra sulfophenyl-porphyrin. Acta Physiol. Hung. 97, 41-51 https://doi.org/10.1556/APhysiol.97.2010.1.5

Cooke MS, Evans MD, Miral D, Joseph L (2003): Oxidative DNA damage: mechanisms, mutation and disease. FASEB J. 17, 1195-214 https://doi.org/10.1096/fi.02-0752rev

Crozier A, Jaganath IB, Clifford MN (2009): Dietary phenolics: chemistry, bioavailability and effects on health. Nat. Prod. Rep. 26, 1001-1043 https://doi.org/10.1039/b802662a

Dal-Pizzol F, Ritter C, Klamt F, Andrades M, Frota ML, Diel C, Lima C, Filho AB, Schwartsmann G, Moreira JC (2003): Modulation of oxidative stress in response to gamma radiation in human glioma cell lines. J. Neurooncol. 61, 89-94 https://doi.org/10.1023/A:1022168805198

Ferenc P, Solár P, Kleban J (2010): Down-regulation of Bcl-2 and Akt induced by combination of photoactivated hypericin and genistein in human breast cancer cells. J. Photochem. Photobiol. B 98, 25-34 https://doi.org/10.1016/j.jphotobiol.2009.10.004

Frank J, Flaccus A, Schwarz C (2006): Ascorbic acid suppresses cell death in rat DS-sarcoma cancer cells induced by 5 -aminolevulinic acid-based photodynamic therapy. Free Radic. Biol. Med. 40, 827-836 https://doi.org/10.1016/j.freeradbiomed.2005.10.034

Garland MJ, Cassidy CM, Woolfson D, Donnelly RF (2009): Designing photosensitizers for photodynamic therapy: strategies, challenges and promising developments. Future Med. Chem. 1, 667-691 https://doi.org/10.4155/fmc.09.55

Glasauer A, Chandel NS (2014): Targeting antioxidants for cancer therapy. Biochem. Pharmacol. 92, 90-101 https://doi.org/10.1016/j.bcp.2014.07.017

González MJ, Miranda-Massari JR, Mora EM, Guzmán A, Riordan NH, Riordan HD, Casciari JJ, Jackson JA, Román-Franco A (2005): Orthomolecular oncology review: ascorbic acid and cancer 25 years later. Integr. Cancer Ther. 4, 32-44 https://doi.org/10.1177/1534735404273861

González MJ, Miranda-Massari JR (2006): Advances in vitamin C research. Integr. Cancer Ther. 5, 7-8 https://doi.org/10.1177/1534735405286108

Gopalakrishna R, Gandimeda U (2002): Antioxidant regulation of protein kinase $\mathrm{C}$ in cancer prevention. J. Nutr. 132, 3819-3823 https://doi.org/10.1093/jn/132.12.3819S

Ion RM (2010): Derivative UV-Vis spectrophotometry for porphyrins interactions in photodynamic therapy. Anal. Lett. 43, 1277-1286 https://doi.org/10.1080/00032710903518690 
Israel K, Yu W, Sanders BG, Kline K (2000): Vitamin E succinate induces apoptosis in human prostate cancer cells: role for fas in vitamin E succinate-triggered apoptosis. Nutr. Cancer 36, 90-100 https://doi.org/10.1207/S15327914NC3601_13

Jentzsch AM, Bachmann H, Fürst P, Biesalski HK (1996): Improved analysis of malondialdehyde in human body fluids. Free Radic. Biol. Med. 20, 251-256 https://doi.org/10.1016/0891-5849(95)02043-8

Laranjinh J, Vierira O, Almeid L, Modeira V (1996): Inhibition of metmyoglobin $\mathrm{H} 2 \mathrm{O} 2$-dependent low density lipoprotein lipid peroxidation by naturally occurring phenolic acid. Biochem. Pharmacol. 51, 395-402 https://doi.org/10.1016/0006-2952(95)02171-X

Larrosa M, Tomas-Barberan FA, Espin JC (2006): The dietary hydrolysable tannin punicalagin releases ellagic acid that induces apoptosis in human colon adenocarcinoma Caco- 2 cells by using the mitochondrial pathway. J. Nutr. Biochem. 17, 611-625 https://doi.org/10.1016/j.jnutbio.2005.09.004

Li TM, Chen GW, Su CC, Lin JG, Yeh CC, Cheng KC, Chung JG (2005): Ellagic acid induced p53/p21 expression, G1 arrest and apoptosis in human bladder cancer T24 cells. Anticancer Res. 25, 25971-979

Losso JN, Bansode RR, Trappey A, Bawadi H, Truax R (2004): In vitro antiproliferative activities of ellagic acid. J. Nutr. Biochem. 15, 672-678 https://doi.org/10.1016/j.jnutbio.2004.06.004

Martijn T, Paul B, Schellens JHM, Stewart FA (2006): Photodynamic therapy in oncology. Oncologist 11, 1034-1044 https://doi.org/10.1634/theoncologist.11-9-1034

Mertens SU, Bomser JC, Talcott ST, Percival SS (2004): Ellagic acid potentiates the effect of quercetin on p21waf1/cip1, p53 and MAP-kinases without affecting intracellular generation of reactive oxygen species in vitro. J. Nutr. 135, 609-614 https://doi.org/10.1093/jn/135.3.609

Mroz P, Huang YY, Szokalska A, Zhiyentayev T, Janjua S, Nifli AP, Sherwood ME, Ruzié C, Borbas KE, Fan D, Krayer M, et al. (2010): Stable synthetic bacteriochlorins overcome the resistance of melanoma to photodynamic therapy. FASEB J. 24, 3160-3170 https://doi.org/10.1096/fj.09-152587

Niedre M, Patterson MS, Wilson BC (2002): Direct near-infrared luminescence detection of singlet oxygen generated by photodynamic therapy in cells in vitro and tissues in vivo. Photochem. Photobiol. 75, 382-391 https://doi.org/10.1562/0031-8655(2002)0750382DNILDO2.0. $\mathrm{CO} 2$

Ogilby PR (2010): Singlet oxygen: there is indeed some thing new under the sun. Chem. Soc. Rev. 39, 3181-3209 https://doi.org/10.1039/b926014p

Oidovsambuu S, Kim CY, Kang K, Dulamjav B, Jigjidsuren T, Nho CW (2013): Protective effect of Paeonia anomala extracts and constituents against tert butylhydroperoxide induced oxidative stress in HepG2 cells. Planta Med. 79, 116-122 https://doi.org/10.1055/s-0032-1328062

Ozben T (2007): Oxidative stress and apoptosis: impact on cancer therapy. J. Pharm. Sci. 96, 2181-2196 https://doi.org/10.1002/jps.20874
Pari L, Sivasankari R (2008): Effect of ellagic acid on cyclosporine A-induced oxidative damage in the liver of rats. Fund. Clin. Pharmacol. 22, 395-401 https://doi.org/10.1111/j.1472-8206.2008.00609.x

Prasad K, Cole W, Kumar B, Prasad K (2001): Scientific rationale for using high-dose multiple micronutrients as an adjunct to standard and experimental therapies. J. Am. Coll. Nutr. 20, 450S-463S https://doi.org/10.1080/07315724.2001.10719184

Rehman MU, Tahir M, Ali F, Qamar W, Lateef A, Khan R, Quaiyoom A, Hamiza OO, Sultana S (2012): Cyclophosphamideinduced nephrotoxicity, genotoxicity, and damage in kidney genomic DNA of Swiss albino mice: theprotective effect of Ellagic acid. Mol. Cell. Biochem. 365, 119-127 https://doi.org/10.1007/s11010-012-1250-X

Richardson MA, Sanders T, Palmer JL, Greisinger A, Singletary SE (2000): Complementary/alternative medicine use in a comprehensive cancer center and the implications for oncology. J. Clin. Oncol. 18, 2505-2514

https://doi.org/10.1200/JCO.2000.18.13.2505

Rogerio AP, Fontanari C, Borducchi E, Keller AC, Russo M, Soares EG, Albuquerque DA, Faccioli LH (2008): Anti-inflammatory effects of Lafoensia pacari and ellagic acid in a murine model of asthma. Eur. J. Pharmacol. 580, 262-270 https://doi.org/10.1016/j.ejphar.2007.10.034

Rubio N, Verrax J, Dewaele M, Verfaillie T, Johansen T, Piette J, Agostinis P (2014): p38MAPK-regulated induction of p62 and NBR1 after photodynamic therapy promotes autophagic clearance of ubiquitin aggregates and reduces reactive oxygen species levels by supporting Nrf2-antioxidant signaling. Free Radic. Biol. Med. 67, 292-303

https://doi.org/10.1016/j.freeradbiomed.2013.11.010

Rutz HP, Little JB (1981): Modification of radiosensitivity and recovery from X-ray damage in vitro by retinoic acid. Int. J. Rad. Oncol. Biol. Phys. 16, 1285-1288 https://doi.org/10.1016/0360-3016(89)90300-3

Salganik RI (2001): The benefits and hazards of antioxidants: controlling apoptosis and other protective mechanisms in cancer patients and the human population. J. Am. Coll. Nutr. 20, 464S-472S https://doi.org/10.1080/07315724.2001.10719185

Seeram NP, Adams LS, Henning SM, Niu Y, Zhang YJ, Nair MG, Heber D (2005): In vitro antiproliferative, apoptotic and antioxidant activities of punicalagin, ellagic acid and a total pomegranate tannin extract are enhanced in combination with other polyphenols as found in pomegranate juice. J. Nutr. Biochem. 16, 360-367 https://doi.org/10.1016/j.jnutbio.2005.01.006

Seifried HE, Nald SS, Anderson DE, Peter G, Milner JA (2003): The antioxidant conundrum in cancer. Cancer Res. 63, 4295-4298

Singh NP, McCoy MT, Tice RR, Schneider EL (1988): A single technique for quantification of low levels of DNA damage in individual cell. Exp. Cell. Res. 175, 184-191 https://doi.org/10.1016/0014-4827(88)90265-0

Sun D, Zhang SJ, Wei YF, Yin LF (2009): Study on antioxidants activities of mangostin and its effect to K562 leukemia cell in photodynamic therapy. Acta Biochim. Biophys. Sin. 41, 1033-1043 https://doi.org/10.1093/abbs/gmp099 
Türk G, Çeribaşi AO, Sakin F, Sönmez M, Ateşşahin A (2010): Antiperoxidative and antiapoptoticahineffects of lycopene and ellagic acid on cyclophosphamide-induced testicular lipid peroxidation and apoptosis. Reprod. Fert. Develop. 22, 587-596 https://doi.org/10.1071/RD09078

Türk G, Sönmez M, Çeriba AO, Yüce A, Ateşşahin A (2010): Attenuation of cyclosporine A-induced testicular and spermatozoal damages associated with oxidative stress by ellagic acid. Int. Immunopharmacol. 10, 177-182 https://doi.org/10.1016/j.intimp.2009.10.013

Vattem DA, Shetty K (2003): Ellagic acid production and phenolic antioxidant activity in cranberry pomace (Vaccinium macrocarpon) mediated by Lentinus edodes using a solid-state system. Process Biochem. 39, 367-379 https://doi.org/10.1016/S0032-9592(03)00089-X

Wu SM, Ren QG, Zhou MO, Peng Q, Chen JY (2003): Protoporphyrin IX production and its photodynamic effects on glioma cells, neuroblastoma cells and normal cerebellar granule cells in vitro with 5-aminolevulinic acid and its hexylester. Cancer Lett. 200, 123-131 https://doi.org/10.1016/S0304-3835(03)00271-4

Zambuchini B, Fiorini D, Verdenelli MC, Orpianesi C, Ballini R (2008): Inhibition of microbiological activity during sole (Solea solea L) chilled storage by applying ellagic and ascorbic acids. LWT Food. Sci. Technol. 41, 1733-1738
Zhang W, Hashimoto K, Sakagami H (2002): Decline of superoxide dismutase activity during antioxidant induced apoptosis in HL-60 cells. Anticancer. Res. 22, 219-224

Zhang SJ, Zhang ZX (2004): 5-Aminolevulinic acid based photodynamic therapy in leukemia cell HL60. Photochem. Photobiol. 6, 545-550 https://doi.org/10.1562/MU-03-32.1

Zhang SJ, Sun D, Hao JB, Wei YF, Yin LF, Liu X (2012): The effect of dietary soyabean isoflavones on photodynamic therapy in K562 leukemia cells. J. Photochem. Photobiol. B 110, 28-33 https://doi.org/10.1016/j.jphotobiol.2012.02.006

Zhao M, Tang SN, Marsh JL, Sharmila S, Srivastava RK (2013): Ellagic acid inhibits human pancreatic cancer growth in Balb c nude mice. Cancer Lett. 337, 210-217 https://doi.org/10.1016/j.canlet.2013.05.009

Ziech D, Franco R, Georgakilas AG, Georgakila S, Malamou-Mitsi V, Schoneveld O, Pappa A, Panayiotidis MI (2010): The role of reactive oxygen species and oxidative stress in environmental carcinogenesis and biomarker development. Chem. Biol. Interact. 188, 334-339 https://doi.org/10.1016/j.cbi.2010.07.010

Received: August 11, 2017

Final version accepted: September 25, 2017 